\title{
Contingency Theory and
}

\section{The Effect of Mediation In Doing Business}

Nama : afan miftakhul huda

Email : afanmiftakhulhuda@gmail.com

Kontigensi adalah sebuah teori yang menyatakan bahwa tidak ada sebuah rancangan dan penggunaan sebuah sistem pengendalian manajemen yang dapat diberlakukan atau dijalankan secara efektif untuk situasi organisasi, maupun sebuah perusahaan tertentu. Dalam kata lain bagaimana cara sebuah perusahaan untuk menyelaraskan kinerja yang diharapkan dengan lingkungan bisnis internal dan eksternalnya (Homburg, Artz, \& Wieseke, 2012).

Dikutipan sebuah jurnal (pratono) menyebutkan bahwa teknologi informasi memberikan sebuah tantangan tersendiri bagi kinerja UKM. Turbulensi yaitu suatu proses yang mengubah dampak variabel independen terhadap kinerja perusahaan dalam konteks teori kontigensi. UKM yang memiliki orientasi strategis yang besar dapat menigkatkan kinerjanya. Namun, berbagai turbulensi teknologi dinamis memberikan dampak yang berbeda pada hubungan antara orientasi strategis dan kinerja perusahaan. Hal ini menunjukkan bahwa terdapat skala daya serap UKM untuk memanfaatkan teknologi (Alexi, George, \& Salter, 2013).

Menegaskan karya Shin dan Lee (2013), yang berpendapat bahwa UKM harus mempertimbangkan peluang arbitrase teknologi yang berisiko rendah dalam teknologi yang sudah matang, yang dimana harus memperluas diskusi tentang mengapa perusahaan mengambil risiko dengan membuat keputusan untuk mengadopsi teknologi yang sangat spekulatif. dengan kemungkinan kecil untuk mencapai kesuksesan komersial yang signifikan, sementara perusahaan lain tetap mengejar teknologi lama (Ross, 2014).

Untuk meraih sebuah proses kinerja yang maksimal dari sebuah perusahaan, maka diharapkan untuk mengadopsi otonomi kewirausahaan pada mekanisme penetapan harga yang melibatkan parameter harga yang menyesuaikan diru untuk mempertimbangkan persyaratan aplikasi dan layanan pengguna (Yeo, Venugopal, Chu, \& Buyya, Yeo et al. 2010). ini menunjukkan harga kapabilitas yang menunjukkan bagaimana perusahaan menentukan harga untuk menghasilkan laba (Murray, Gao, \& Kotabe, Murray et al. 2011). Selain itu UKM juga menghadapi sebuah hubungan yang komplek antara kapabilitas harga dan kinerja memerlukan variabel moderasi yang dimana variabel tersbut dapat menjelaskan hubungan tersebut Banterle, Cavaliere, Carraresi, \& Stranieri, Banterle et al. 2014). Yang dimana teknologi ini tidak hanya 
memainkan peran penting, melainkan juga sebagai pendorong perubahan sebuah organisasi yang dimana akan menghasilkan peningkatan produktivitas tambahan (Dedrick, Gurbaxani, \& Kraemer, Dedrick et al. 2003), namun juga akan menimbulkan sebuah ancaman bagi sebuah perusahaan, terutama perusahaan dengan skala yang lebih kecil apalagi dengan sumber daya yang terbatas. Sehingga untuk memanfaatkan peluang, maka perusahaan akan lebih berusaha lagi untuk tetap dekat dengan pelanggan mereka dengan mempromosikan otonomi kewirausahaan kepada staf lini depan (Pratono 2016).

Mediasi yaitu cara atau suatu tindakan untuk mengambil sebuah keputusan yang dimana melibatkan pihak ketiga yang tidak memiliki sangkut pautnya dengan masalah dari kedua belah pihak yang dimana pihak ketiga ini tidak memberikan keputusan atas permasalahan yang sedang dihadapi oleh kedua pihak tersebut. Sehingga pihak ketiga ini hanya memberikan solusi namun yang memutuskan adalah kedua pihak sedang bingung dalam memilih keputusan yang cocok dengan keadaan yang sedang terjadi.

Misalkan saja UKM adalah bisnis berisiki tinggi dan perusahaan yang lebih besar dapagt menigkatkan kapasitas untuk mengakses segala hal yang llebih banyak daripada UKM yang dimana struktur organisasinya lebih sederhana. Sehingga (Falker dan Hiebl, 2015) membuat teori bahwa struktur organisasi yang sederhana dan fleksibel ini akan mudah dalam mrespon perubahan lingkungan yang dinamis atau selalu berubah namun akan mendapat keuntungan yang kecil dibandingkan dengan perusahaan yang lebih besar. Sehingga (Zellweger dan Sieger,Situmeang et al.,2016) mengambil jalan tengah yaitu dengan strategi orientasi jangka panjang mengarah UKM menjadi pengambil risiko dengan memanfaatkan kemampuan manajemen yang mereka miliki secara efektif. Namun disisi lain diusahakan penghindaran risiko mengacu pada periaku perusahaan yang berkaitan dengan menghindari dan menetap dalam zona nyaman nyaman (Lichtenthaler dan Muethel, 2012).

Dalam hal penetapan harga UKM juga belum memahami matangnya kapabilitas dalam menentukan harga sehingga belum mengetahui perbandingan risiko dan juga manfaat untuk memahami teknologi IT (Kim et al., 2016). Namun menurut (Pratono, 2016) apabila UKM berniat untuk memanfaatkan tpeluang bisnis nanti akan mencapai kerja yang sangat tinggi di bawah turbulrnsi teknologi yang diamana akan dapat diprediksi. Namun akan sebaliknya jika UKM yang memiliki teknologi dan pasar yang terbatas karena pengeluaran R\%D yang sangat rendah dan ketergantungan akan sebuah produk yang terbatas.

Namun, apabila perushaan terlalu berambisi dalam berinovasi juga harus menghadapi risiko kesalahan dalam hal mngembil keputusan yang lebih tinggi juga. Hal ini juga selaras dengan (Zhang \& Duan, 2010) bahwa perusahaan yang berorientasi peluang dapat menigkatkan risiko bisnis yang lebih besar. Sehingga hal ini menantang UKM untuk beradaptasi dengan perubahan pasar yang akan terjadi yaitu ketidakmampuan untuk menanggapi peluang telah menyebabkan kematian banyak perusahaan (Kumar, Jones, Venkatesan, \& Leone, 2011). Karena lingkungan bisnis yang tidak dapat 
diprediksi sehingga berbagai informasi berharga akan gagal dipahami dan diidentifikasi berbagai informasi tersebut.

\section{References}

Homburg, C., Artz, M., \& Wieseke, J. (2012). Marketing Performance Measuremant Systems: Does Comprehensiveness Really Improve Performance? Journal Of Marketing, 76 (5), 5677.

Pratono, A.H. (2016). Strategic Orientation And Information Technological Turbulence: Contingency Perspective In. Business Process Management, 22(2). Https://Doi.Org/10.1108/Bpmj-05-2015-0066।

Pratono, A.H. (2018), Does Firm Performance Increase With Risk-Taking Behavior Under Information Technological Turbulence? Empirical Evidence From Indonesian Smes", Journal Of Risk Finance, 19(4), 361-378. Https://Doi.Org/10.1108/Jrf-10-2017-0170

Alexy, O., George, G., \& Salter, A. (2013). Cui Bono? The Selective Revealing Of Knowledge And Its Implications For Innovative Activity. Academy Of Management Review, 38 (2), 270290.

Ross, D.G. (2014), “Taking A Chance: A Formal Model Of How Firms Use Risk In Strategic Interaction With Other Firms", Academy Of Management Review, Vol. 39 No. 2, Pp. 202226.

Falker, E.M. And Hiebl, M.R. (2015), "Risk Management In Smes: A Systematic Review Of Available Evidence", The Journal Of Finance, Vol. 16 No. 2, Pp. 122-144.

Situmeang, F.B., Gemser, G., Wijnberg, N.M. And Leenders, M.A. (2016), "Risk-Taking Bahavior Of Technology Firms: The Role Of Performance Feedback In The Video Game Industry", Technovation, Vol. 54, Pp. 22-34.

Lichtenthaler, U. And Muethel, M. (2012), "The Impact Of Family Involvement On Dynamic Innovation Capability: Evidence From German Manufacturing Firms", Entrepreneurship Theory And Practice, Vol. 36 No. 6, Pp. 1235-1253.

Kim, S.H., Jang, S.Y. And Yang, K.H. (2016), "Analysis Of The Determinants Of Software-AsAService Adoption In Small Business: Risks, Benefits, And Organizational And Environmental Factors", Journal Of Small Business Management, Vol. 55 No. 2, Pp. 303325.

Pratono, A.H. (2016), "Strategic Orientation And Information Technological Turbulence: Contingency Perspective In Smes", Business Process Management Journal, Vol. 22 No. 2, Pp. 368-382.

Pratono, A.H. (2018), "From Social Network To Firm Performance: The Mediating Effect Of Trust, Selling Capability And Pricing Capability", Management Research Review, Vol. 41 No. 6, Pp. 680-700. 
Zhang, J., \& Duan, Y. (2010). The impact of different types of market orientation on product innovation performance. Management Decision, 48 (6), 849-867.

Kumar, V., Jones, E., Venkatesan, R., \& Leone, R. (2011). Is market orientation a source of sustainable competitive advantage or simply the cost of competing? Journal of Marketing , 75 (1), 16-30. 